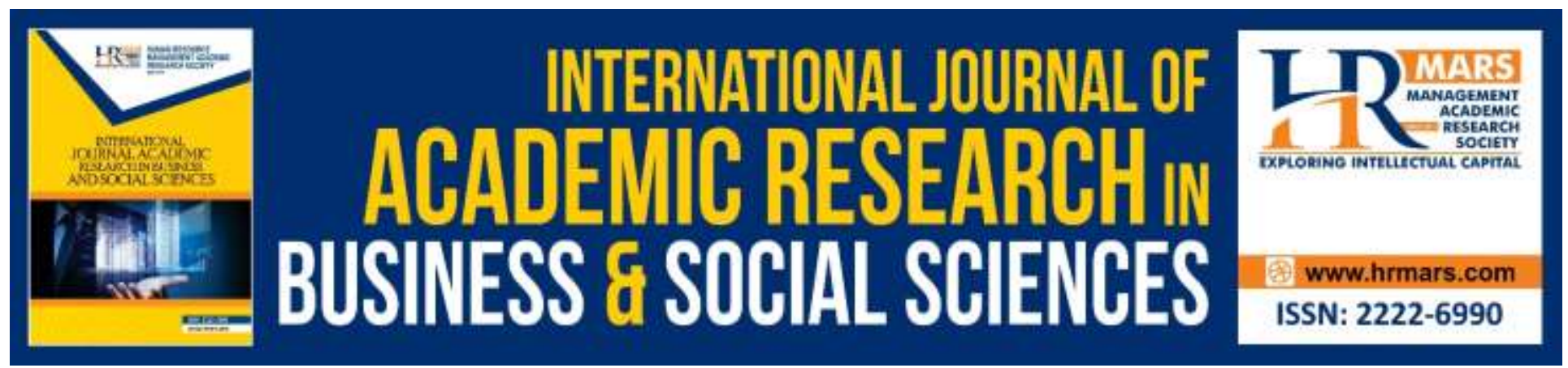

\title{
Principals' Acceptance of School Improvement Partners Mentoring Practice in Malaysia
}

\section{Iskandar Padzil, Suhaida Abdul Kadir, Ahmad Fauzi Mohd Ayob \& Mohd Mursyid Arshad}

To Link this Article: http://dx.doi.org/10.6007/IJARBSS/v9-i11/6711

DOI: 10.6007/IJARBSS/v9-i11/6711

Received: 04 October 2019, Revised: 27 October 2019, Accepted: 06 November 2019

Published Online: 30 November 2019

In-Text Citation: (Padzil, Kadir, Ayob, \& Arshad, 2019)

To Cite this Article: Padzil, I., Kadir, S. A., Ayob, A. F. M., \& Arshad, M. M. (2019). Principals' Acceptance of School Improvement Partners Mentoring Practice in Malaysia. International Journal of Academic Research in Business and Social Sciences, 9(11), 1446-1461.

\section{Copyright: (C) 2019 The Author(s)}

Published by Human Resource Management Academic Research Society (www.hrmars.com)

This article is published under the Creative Commons Attribution (CC BY 4.0) license. Anyone may reproduce, distribute, translate and create derivative works of this article (for both commercial and non-commercial purposes), subject to full attribution to the original publication and authors. The full terms of this license may be seen

at: http://creativecommons.org/licences/by/4.0/legalcode

\section{Vol. 9, No. 11, 2019, Pg. 1446 - 1461}

Full Terms \& Conditions of access and use can be found at http://hrmars.com/index.php/pages/detail/publication-ethics 


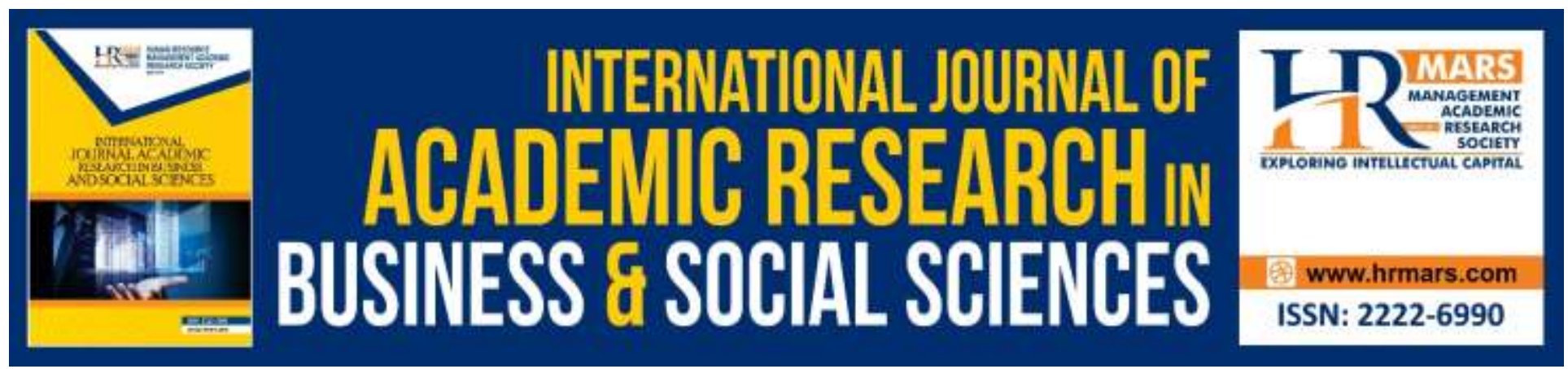

\title{
Principals' Acceptance of School Improvement Partners Mentoring Practice in Malaysia
}

\author{
Iskandar Padzil, Suhaida Abdul Kadir, Ahmad Fauzi Mohd Ayob \& \\ Mohd Mursyid Arshad
}

Faculty of Educational Studies, Universiti Putra Malaysia (UPM), Selangor, Malaysia

\begin{abstract}
The purpose of this paper is to explore the principals' acceptance of School Improvement Partners (SIPartners+) mentoring practice in selected secondary schools in East Malaysia. The case study of four principals in low-performance school was qualitative and interpretive. This paper shows that mentoring practice was still less acceptable by the school principals as they felt that SIPartners+ as an outsider who intervene the school management. The findings dereived from four research questions which related to the needs of mentoring, SIPartners+ competency, SIPartners+ knowledge and SIPartners+ experience. These findings were limited to the sample of principals used for this analysis. Researchers are encouraged to examine SIPartners+ mentoring in other contexts. The results of this research suggested for the practitioners to reflect on their roles in education collaboratively and call for further research on SIPartners+ practices between urban and rural schools. This paper is one of the few documents that studies mentoring in the Malaysian education system. It forms a basis for future empirical research in this area.
\end{abstract}

Keywords: Principals, School Improvement Partners, Mentoring, Secondary School.

\section{Introduction}

Mentoring is a useful tool in human resource development in organizations (Bullard, 2017; Weinberg et al., 2017). It is identified as an essential concept in the professional development of educators, where it plays a crucial scope in educational development (Holland, 2018; Ng, 2012). Scholars based on their studies gave various definitions but it is acceptable that the term 'mentor' has been widely used to refer to a more experienced adult who is in a high position to lead, help and guide a less experienced adult in the latter's professional and career development (Ragins \& Kram, 2008). The recipient of advice and guidance by the senior expert (mentor) has been variously termed, namely as protégé ( $\mathrm{Ng}$, 2012; Wang, Gurr, \& Drysdale, 2016; Pernamasari, 2018). In Malaysia's education system, mentoring was not stressed much until the forming of the SIPartners+ and SISC+ position in 2013 at the district education offices (Kunalan, 2016). Principals 
need support from others to help them manage the schools to achieve their targets and aims. Becoming a competent principal takes time, even years. Principals who are posted to lowerperforming schools, face more challenges to bring the schools to a better grade and level. Working solely in the high position in school does not guarantee them to be a great leader. For that purpose, the Ministry of Education (MOE) Malaysia had introduced the SIPartners+ position to help them to reduce their burden in managing the school. However, since it was implemented in the Malaysian education system, do principals accept their presence in the school, especially in mentoring them? This paper, the researcher is focusing on the roles of SIPartners+ as a mentor for the principal in low-performance secondary schools and explore the principals' acceptance of their mentoring practice towards them.

\section{Rationale}

Studies on mentoring in the USA and UK traditionally been conducted in the business and industrial settings, as well as some key government department (Boon, 1998). In the late 1980s, researchers changed the direction of studies on mentoring in the field of education in line to improve the education system in their countries. Mentoring has gained popularity in the training of teachers and school administrators, either in primary or secondary school (Daly \& Milton, 2017). In education, mentoring is a complex and multi-dimensional process of guiding, teaching, influencing and supporting a beginning or new teacher (Hansford \& Ehrich, 2006; Shanks, 2017). It is generally accepted that a mentor leads, guides and advises another more junior and inexperience teacher in a work situation characterized by mutual trust and belief (Lejonberg, Elstad, \& Christophersen, 2015). In Malaysia education context, SIPartners+ mentoring is still in its early practices as it was newly implemented in 2012. As it was pioneered in two states, namely Sabah and Kedah, their roles in helping the principals managing the school are still seen as an outsider who is trying to interfere with the school management. As such, further studies related to mentoring by SIPartners+ is vital for knowing the principals' perception toward it.

\section{Research Question}

There are four research questions in this study.

1. What is your perception towards the need of SIPartners+ mentoring in your school?

2. What is your perception towards SIPartners+ competency?

3. What is your perception towards SIPartners+ knowledge?

4. What is your perception towards SIPartners+ experience?

\section{School Improvement Partner Plus (SIPartners+) in Malaysia Education System}

The growth of education planning in Malaysia had changed the policy and practices in line to develop the quality of education in Malaysia. A few changes in the development of principal leadership enables the government to implement a few improvements, especially in the practice of managing the school. Malaysia Education Blueprint 2013-2025 had stated three waves of implementation, i.e. First Wave (2013-2015), Second Waves (2016-2020) and Third Wave (20212025) (Ministry of Education, 2012). Each wave is designed to have specific focus and approaches 
which have been delegated by the Ministry of Education. The First Wave emphasizes the improvement of the education system by changing the method of implementation. The main focus of this wave is to pay attention to teaching methods and improving the quality of school leaders. Thus, by the end of First Wave, all teachers, school administrators and the school has reached a minimum quality standard set by the Ministry of Education.

The second wave focuses on implementing changes in the structure of the national education system. The implementation that involves all teachers and school administrators is the provision of new career packages and the restructuring of all ministries. In implementing the change process, the State Education Department and the District Education Office played an essential role in providing relevant information to the ministry. The Third Wave emphasizes the performance aspects of individuals and schools under the Ministry of Education Malaysia. All schools, teachers and school administrators are required to show the minimum standard of performance set by the ministry. As such, the Ministry of Education Malaysia will focus on increasing operational flexibility to foster peer-to-peer leadership for professional development among educational people. One of the development programs introduced in the Malaysia Education Blueprint is the District Transformation Program (DTP), where one of the key aspects of the program is the School Improvement Partners Plus (SIPartners+).

Researchers, policymakers, and practitioners increasingly recognize the role of school leaders in developing high-performing schools (Darling-hammond, LaPointe, Meyerson, Orr, \& Cohen, 2007). There has been growing attention to the crucial role of school leaders in cultivating the quality of education. Largely unnoticed in the various reform movements of the past two decades, principals are now viewed as central to the task of building schools that promote powerful teaching and learning for all students, rather than merely maintaining the status quo (Celoria \& Roberson, 2015). Leadership is the critical point of the effective school whereby the school leaders will bring the subordinates to be more effective (King Jr. et al., 2017; Sani, Zabidi, Razak, \& Banu, 2013). Therefore, to enhance the skills and competencies of the leaders in managing the school, School Improvement Partners Plus (SIPartners+) was formed by the Ministry of Education (MOE) under the District Education Office control to ensure the DTP under the Malaysia Education Blueprint 2013-2025 is fully implemented. The central role of SIPartners+ is to guide the principals in terms of school leadership and management to improve the competence of school leaders (Siti Anida, 2012). As a front line officer who is assigned to spearhead the improvement of school standards and performance, their role is crucial to support the development of the system in the Second Wave implementation of Malaysia Education Blueprint (2016-2020).

This program provides professional development support for principals in low performing schools. Principals will benefit from this program as they will get direct guidance from appointed SIPartners+. The program aims to ensure individual professional development is fulfilled based on the criterion stated by MOE. In guaranteeing the effective role of SIPartners + , each SIPartners 
+ appointed by the Ministry of Education Malaysia should understand their duties and responsibilities in guiding the principals monitored by the objectives outlined by the Ministry of Education Malaysia (Ministry of Education, 2017). The ability, mental and emotional strength of SIPartners + is critical to ensure the effectiveness and sustainability of this program as well as having excellent skills for implementing mentoring in prescribed schools (Kunalan, 2016). The primary step of the SIP program is to evaluate schools in Malaysia, to motivate and assist principals in developing school management and leadership systems according to their school environment and climate.

The new SIPartners + mentoring program is set to start in the 5th year since it was introduced in 2013 involving two pioneer states namely Kedah and Sabah, with 150 SIPartners+ being appointed by the Ministry of Education Malaysia based on the established criterion. In 2014, this mentorship and posts program was extended to all states in Malaysia by placing qualified and appointed SIPartners+ officers based on expertise at each District Education Office. In 2015, nearly 1500 SIPartners+ were appointed and served in their respective District Education Offices. The SIPartners+ program was found to support the creation of more authoritative principals based on the mentoring programs that have been carried out (Hill, 2016). The SIPartners+ build and assist school leaders in improving students achievement and bringing the school to a higher level of performance (Shanks, 2017). School principals who have been guided and mentored are more likely to bring a positive impact on school effectiveness (Ng, 2012; Russo, 2013).

The existence of SIPartners+ in the education system has changed the landscape and educational perspectives, especially in the leadership of the school in the effort of producing high performing schools. Their role as a mentor will guide principals and teachers in improving leadership capabilities in schools. In crossing the flow of modernity and challenges of globalization, principals are required to have strong leadership competencies and are willing to accept any changes set by the Ministry of Education Malaysia in line with the rapid development of education. The mentoring program undertaken in schools is expected to produce creative, innovative and capable leaders in addressing challenges in promoting educational institutions to a productive community development platform.

Hill (2016) believes that smart sharing programs can support the leaders to manage the school more effectively and proactively. Through mentoring processes, mentors can share a more comprehensive and practical way of solving a problem ( $\mathrm{Ng}, 2012$; Shanks, 2017). The mentoring process allows an education leader to interact directly with their mentor by expressing any issues in their organization without any disturbance, complicated protocols and external threats (Dutton, 2003; Weinberg et al., 2017).

\section{Problem Statement}

The existence of SIPartners+ posts in the national education system is one of the initiatives of the Ministry of Education in promoting education systems towards global education and towards the 
developed countries (Ministry of Education, 2017). Studies on the role and effectiveness of the SIPartners+ in the Malaysian education system are less because of the introduction of new technologies in 2013 (Sharifah Sofiah \& Mohd Izham, 2017; Tan, 2015). The study conducted by Kunalan (2016) only looks at the impact of the implementation of SIPartnerst on principals' leadership in general and its effect on the achievement of secondary schools in Sabah without justifying the SIPartners+ mentoring practice. In 2016, pilot studies conducted by Aminuddin Baki Institute, Ministry of Education Malaysia related to the impact of the SIPartners+ guidance visit program. However, this study only involved selected schools in Peninsular Malaysia, and the findings only refer to the impact of SIPartners+ guidance involving four dimensions; namely SIPartners+ personality, principal acceptance, counselling approach and SIPartners+ mentoring effect regardless of the role of SIPartners+ as a mentor in school management.

Sharifah Sofiah and Mohd Izham (2017) and Tan (2015) did their studies on SIPartners+ in Malaysia context where their studies focus only on the implementation of the SIPartners+ program with the quality of education. However, their studies conducted on small locations known as Bangsar-Pudu Zone, Kuala Lumpur and Johor state. Tan (2015) in her study stated that most SIPartners+ were not accepted by the principals in schools. The school leaders saw SIPartners+ as an outsider trying to intervene in school affairs. Tan further stated that SIPartners+ is an external mentor to a school organization; hence, the principal does not want to be seen as an inexperienced administrator in managing the school. However, some principals received SIPartners+ visits as a link to the District Education Office to solve school problems such as lack of teachers, lack of infrastructure and fund (Chapman et al., 2014). Most researchers only looked at the effectiveness of the SIPartners+ program with school performance, especially in the academic field regardless of the primary role of SIPartners+ in the Malaysian education system. Their primary role in the Malaysian education system is to provide mentoring to principals. Specific studies related to SIPartners+ mentoring approaches are less discussed in previous studies. Moreover, most studies related to SIPartners+ in Malaysia were conducted in quantitative, and only a few qualitative research done.

\section{Methodology}

This study is a case study using a qualitative approach. The case study was conducted through indepth interview with four low-performance school principals in the state of Sabah, East Malaysia. THE present study explored their acceptance of SIPartners+ mentoring practice during their visit to schools. The selection of qualitative case study methods was also contributed by the research interest to explore, to discover and interpret rather than to test hypothesis. The design of this type of research is done by researchers based on the advantages the following: (1) involves a number of similar cases, (2) an internal replication a variety of cases that can produce similar patterns in relation to phenomena investigated and (3) each case may produce the same or different findings. 


\section{Limitations}

This study has several limitations. It focuses on low-performance secondary schools in Sabah, East Malaysia. Consequently, the findings may not apply to all other secondary schools; however, they might be transferable to other similar school situations and settings. This study was limited by the number of participants and the level of school performances. Furthermore, four secondary school principals were selected based on their school band in 2016, reported by MOE.

\section{Principal A}

Principal $A$ is a senior principal holding a higher grade in the education system. She has been posted as a principal for 15 years in different schools. Her current school is her fourth school. It is graded a Band 5 school. Even though the school is located in the urban area, the students' background and environment are other key factors that influence the school performances. School A is situated in the outskirt of the central city. The student population is high, with the number close to two thousand students.

\section{Principal B}

Principal B is a principal in a single-sex school in the urban area. The school is located in the centre of the city with a student population of nearly one thousand students. Even though the school is located in the city, the school performance ranges between average and slightly low performance. He has been posted in school B for the past six years as a principal. School B is Principal B's first school as a principal.

\section{Principal C}

Principal C is a novice principal after he completed his National Principal Qualification Educational Leadership (NPQEL) course two years ago. He was assigned to be a principal in a big school which graded as Grade A school. School C is located in the suburbs of city with the students' population reaching almost three thousand. School C's performance is graded as low performance based on the educational rating in 2016.

\section{Principal D}

Principal D was assigned to school D in early 2017 after he was posted in the rural area as a principal for seven years. Her experience in managing the rural school helped her the most in managing the new school even though it is a low performing school. She adapted and adopted her skills from the previous school in her new school, especially on administration. School D is a boarding school which accepts students from the vast community and not just academic-based, which results in the school labelled as a low performing school.

\section{Findings}

Overall, mentoring was described as preparation and support and a gratifying form of professional development. Throughout the interviews, SIPartners+ mentoring was positioned as an ongoing process. SIPartners+ mentoring occurred in different ways in the context of the four 
participating principals. The findings encompass the principals' view of mentoring by SIPartners+ in their profession and their acceptance of mentoring.

\section{Research Question 1: What is your Perception towards the Need of SIPartners+ Mentoring in your School?}

During the research interviews, the principals expressed their interpretation of mentoring based on their situations. Principal $B$ and $C$ agreed that mentoring is needed for all principals to manage their school. Principal $C$ shared the following opinion;

'As a new person in this hot seat, I believe that mentoring will help me a lot. I think it is not only for me but for all principals. Learning is a lifelong process, and we have to admit that we are not perfect. So, mentoring is the best solution if we want to be a good leader in the future.'

Besides, mentoring will help them solve issues related to the school management in their school, especially when it comes to school performances academically and students' affair matters. Today's mentoring programs differ from programs thirty years ago in a very different way. Competition among schools to improve their school reputation and prestige need more guidance from the experts primarily from the mentor. However, Principal A and Principal D showed disagreement of the program of mentoring by SIPartners+ as they felt that the role of SIPartners+ is equivalent to the position of school inspectorate who teaches the principal to manage the school. As Principal A said,

'I have been through this mentoring program since I was assigned to be a principal 15 years ago. The inspectorate officers will come to my school to teach how to manage the school. So, what is the purpose of implementing the redundant position as an inspectorate is doing the same thing?'

However, all of them agreed that mentoring is one of the effective ways to be a good leader. Mentoring relationship can be informal and formal.

\section{Research Question 2: What is your Perception towards SIPartners+ Competency?}

Kalbfeisch and Keyton (1995) clarified that the act of mentoring includes providing a model of adult conduct and involves the acts of giving and receiving. The activities of a mentor are varied, and they must be competentt to teach the protégé as they are more experienced in the field. Based on the interviews, most of the principals question the SIPartners+ competencies in providing mentoring to them. Principal A said,

I'm quite surprised when the SIPartners+ who came to assist me showed a lack of competence. He only relied on the theories solely without showing the actual 
implementation. Besides, he was confused and unsure. It seemed like I was the mentor and him, the protege.

Principal B and Principal D supported principal A's view as they suggested the appointed SIPartners+ not referring to the manual solely without assessing the situation based on the current environment. Principal D shared the following, We must be rational and practical when we decide on any decision. We cannot simply refer to the manual without assessing the real situation. As a mentor, they need to show competence and know how to solve the problem. Competency is the primary key to being a successful mentor.

Principal C shared his stance on SIPartners+ competency,

"To be a mentor, SIPartners+ has to be competent in everything related to the task especially in the leadership management and school production. They must adapt to the school situation if they want to know the real meaning of mentoring."

Based on the findings, the principal believes that competence plays an important role in management.

\section{Research Question 3: What is your Perception toward SIPartners+ Knowledge?}

Knowledge is one of the keys to educating and teaching others (Beutel et al., 2017). Without sufficient knowledge, one will not be able to explain something complex. In the context of mentoring for principals, SIPartners+ is required to have adequate knowledge to share with principals. During the interviews, the principals responded to the questions regarding their acceptance of SIPartners+ mentoring practice to them. One of the issues that arose was SIPartners+ knowledge about leadership and school management. Two principals, Principal B and Principal D, shared the same views about SIPartners+ knowledge as Principal D said:

I'm not expecting them to know everything as I knew they are still new in their position. However, to my surprise, he only knows the basic knowledge of management which I think others can get from the book. They should know more about school management especially when it is about decision making.'

Principal B agreed with her view that SIPartners+ should have vast knowledge about management and leadership as they will guide the principal to the right path of school management. As principal B stated during the interview,

'Leadership skills is a basic acquaintance that everyone must know and gain if they want to be a leader. I found that my SIPartners+ is still learning about management. Before he accepts the offer, he must have a strong basic and knowledge about school management as stated by MOE.'

However, Principal A had her views about SIPartners+ knowledge as she accepted that SIPartners+ is still learning and need more knowledge about school management and leadership. 
'School management and leadership are an ongoing process that everyone needs to face if they want to be accepted in the education community. I'm not going to blame them if they are lacking knowledge as they are still new in the SIPartners+ position. However, they must learn fast as most principals see them as experts who can lead them to manage the school.'

The principals suggested that one of the most effective ways for SIPartners+ to master the knowledge for mentoring is by making an internship at schools before they are assigned to be a SIPartners+. Principal C made the following statement:

I'm not expecting them to know everything as I knew they are still new in their position. However, to my surprise, he only knows the basic knowledge of management, which I think others can get from the book. They should know more about school management, especially when it is about decision making.'

\section{Research Question 4: What is your Perception toward SIPartners+ Experience?}

Experience is the best teacher to teach someone to be effective (Aravena, 2018). During the interviews, all principals agreed that SIPartners+ need to have experience as a school administrator be it a senior teacher or a subject head teacher as shared by Principal B.

'Leadership skills are a necessary acquaintance that everyone must know and gain if they want to be a leader. I found that my SIPartners+ is still learning about management. Before he accepts the offer, he must have a strong fundamental and knowledge about school management, as stated by MOE.'

Principal A agreed with Principal B as she had an experience with SIPartners+ who lacked experience in school management.

'School management and leadership are an ongoing process that everyone needs to face if they want to be accepted in the education community. I'm not blaming them if they are lack of knowledge as they are still new in the SIPartners+ position. However, they must learn fast as most principals see them as experts who can lead them to manage the school.'

Experience and learning are the fundamental processes and the primary purpose of mentoring (Holland, 2018). The role of experience is a central force in understanding the parallel journeys of the mentor and mentee and the learning relationship. Experience and development are intertwined. Using one's life experience is the text for self-discovery and learning (Zachary, 2000). 


\section{Discussion}

This study examined the principals' acceptance of SIPartners+ mentoring practice in secondary schools. Overall, principals do not rule out the existence and role of SIPartners + in the Malaysian education system. However, a particular ruling related to their position should be explained in detail to the school community, especially the principals of the school. For the mentoring aspect, the principals disagree with the approach taken by SIPartners+ as they lack experience and knowledge about school management. Some do not accept the SIPartners+ attendance in school are due to the factors as mentioned above, such as lack of management knowledge, lack of experience and less competence in mentoring. As a practice of developing, socializing and supporting leaders, SIPartners+ mentoring emerged as an essential component of the principalship as they are assigned to coach and mentor them. To lay a solid foundation for building an effective learning and mentoring relationship, mentors must have a clear understanding of their own personal journey (Zachary, 2000).

A causal relationship typically emerges between two people when the experienced person is assisting and guiding the inexperienced person to develop competences for his or her new role (Ragins \& Kram, 2007). Mentors typically provide two types of functions for protégé (Kram, 1983). First, a mentor can offer a career function. Career function involves a variety of behaviours that help protégé for the purpose of progress that will be adopted in an organization. These behaviours include mentoring the protégé, supporting their promotion, enhancing their positive exposure to their careers and offering them protection in challenging tasks (Tahir, Said, Daud, Vazhathodi, \& Khan, 2016). The second function is when the mentor acts as a psychosocial function. Psychosocial functions include building trust, intimacy and interpersonal relationships. These include behaviours that enhance professional and personal development, identity, selfesteem, and ability. In addition, other functions in this aspect are to offer acceptance and validation by providing counselling, friendship, and modelling roles (Shanks, 2017).

The principals suggested that one of the effective ways for SIPartners+ to improve their skill on mentoring is by learning more about school administration and leadership in practical rather than theoretical. Furthermore, they suggested the MOE appointed the senior principals or excellent principals to share their experience with the novice SIPartnerst. Besides, SIPartnerst are encouraged to deal with the selected principals who are assigned in the high-performance schools to study in-depth about the mentoring practice.

McNair, Duree and Ebbers (2011) in their study stated that education leaders need to have skills and competencies to lead and managing the institutions. Eddy (2013) in his research he found leadership competence can be developed through training, acquisition of knowledge knowledge and experience throughout the service organization. Competence is a necessary characteristic of do something (Bass \& Bass 2008). Chen and Naquin (2006) define competence as a fundamental characteristic of an individual is needed to do a job for example, skills, knowledge, attitudes, 
beliefs, motives, and attributes; which enables excellent job creation in line with the organization's strategic functions. That leader effective are competent leaders (Hollenback et al. 2006; Bass \& Bass 2008; Rothwell 2010). Competence needs to be identified as it is a fundamental foundation for effective management (Rothwell 2010). Therefore, to ensure organizational excellence, is an important competent leader to be appointed to leading the organization.

The principals believed that mentoring is a helpful approach that can help them to be a better principal in the future. This finding resonates with recent studies that reported multiple benefits of mentoring and its role in supporting, socializing and developing principals (Hill, 2016; Liang \& Augustine-Shaw, 2016; Wang et al., 2016; Weinberg et al., 2017). These findings suggest that the SIPartners+ must be trained well and have sufficient skills to coach and mentor principals. Otherwise, the principals will not be able to perform to their fullest potential. While mentoring is still new for the principals in Malaysia, further research is needed about the effectiveness of formal and informal mentoring for principals in the Malaysian setting.

While the literature has pointed out the benefits of mentoring and coaching, there are many challenges when it comes to their actual practices ( $\mathrm{Ng}, 2012$; Peiser, Ambrose, Burke, \& Davenport, 2018). The principals agreed that having experience is the most important part if they want to mentor and coach the principals. However, there are the everyday problems of whether there are enough experienced SIPartners+ to perform the role for other educators and whether their experience is sufficient. There is an imbalance between the development and reality of mentoring in Malaysia education system. The mentoring development in Malaysia education is still new and need more enhancements from the authorities. SIPartners+ can play a constructive role in helping novice principals strengthen their management skill, boost confidence level and establish their roles as an instructional leader in school (Sciarappa \& Y. Mason, 2014).

Furthermore, the findings of this study delineated SIPartners+ mentoring as to professional development needed by the principals at different career stages. These results support the findings of previous studies on SIPartners+ mentoring and coaching in Malaysia education system (Institut Aminudin Baki, 2016; Kunalan, 2016; Ng, 2012; Vangronigen, Meyers, \& Hitt, 2017). School principals are key to the development and effectiveness of schools. They need support to make sure they are not alone in their position as administrators. Therefore, mentoring is one of the professional activities that can help principals to remain in their role as principals and improve organizational performance in a more effective way (Aravena, 2018; Na, 2017). The findings of Aravena's (2018) study examining the effectiveness of mentoring on novice principals in Chile found that the mentoring process should have a positive relationship with four factors, namely the system, school context, self and professionalism strategy. Based on the findings, the mentor found that appropriate teaching practices, effective school context and effective professional strategies support principals in managing schools more effectively. 
In the context of education in Malaysia, Tahir, Said, David, Vazhathodi, \& Khan (2016) conducted a study on the perception of novice head teachers on teaching practice in Malaysia. The study found that the main benefit of the respondents during this teaching process was that they can improve their leadership skills, strengthen their school management skills, increase their professional value in education, develop their psychological and social aspects as a school leader. In addition, the findings of the study also show that the mentoring obtained can increase their confidence in leading the school towards excellent and effective schools.

\section{Implications}

Several implications should be considered for policy, practice and research. The results of this study point forward the need for the advancement program for SIPartners + to improve their skills and knowledge. For participants in this study, providing and receiving mentoring can enhance their professional growth and further their understanding of the complexities of mentoring.

\section{Implications for Policy}

Implications for policy include addressing the expectations of school leaders and SIPartners+ being involved with the mentoring process as a mentor, mentee or both. Human resource policies, particularly those dealing with performance evaluation and recruitment, should include language that encourages veteran school leaders to actively engage in mentoring aspiring and novice SIPartners+ and principals.

\section{Implications for Practice}

School system leaders should recognize that as a socialization strategy, mentoring is a powerful source of information for newcomers like SIPartners+ and novice principal.

\section{Implications for Research}

This study analyzed SIPartners+ mentoring in selected schools only based on the principals' view. Further research may further examine the view of SIPartners+ regarding their mentoring to the school and what are their expectations of mentoring.

\section{Conclusion}

In conclusion, the principals need to accept the existence of SIPartnerst in the educational system as they are the frontline officer who can guide them to be a better leader. The improvement and development of their mentoring and coaching conducted by the government are learned to be time-consuming. Moreover, the principals worked in close physical proximity to one another, within the same district and even in the same building as the SIPartners+. Because the principals and SIPartners+ had respectful and professional relationships, mentoring could have been a logical step. Then again, it is not the sole responsibility of SIPartners+ to mentor the principal. There must be two-way communication between a mentor and a mentee. Mentoring needs to be an essential component in a program to develop and prepare the school leaders to lead the school (Chapman et al., 2014). 
INTERNATIONAL JOURNAL OF ACADEMIC RESEARCH IN BUSINESS AND SOCIAL SCIENCES

Vol. 9, No. 11, November, 2019, E-ISSN: 2222-6990 @ 2019 HRMARS

\section{Corresponding Author}

Suhaida Abdul Kadir (PhD) is associate professor at the Faculty of Educational Studies, Universiti Putra Malaysia (UPM), Serdang, Selangor, Malaysia. Email: suhaida@upm.edu.my

\section{References}

Aravena, F. (2018). Mentoring novice school principals in Chile: what do mentors learn ? International Journal of Mentoring and Coaching in Education, 7(3), 219-230. https://doi.org/10.1108/IJMCE-01-2018-0002

Bass, B. M. \& Bass, R. 2008. The Bass Handbook of Leadership: Theory, Research and Managerial Applications. Edisi ke-4. New York: Free Press.

Beutel, D., Crosswell, L., Willis, J., Spooner-Lane, R., Curtis, E., \& Churchward, P. (2017). Preparing teachers to mentor beginning teachers: an Australian case study. International Journal of Mentoring and Coaching in Education, 6(3), 164-177. https://doi.org/10.1108/IJMCE-042017-0030

Boon, S. L. Z. (1998). Principalship mentoring in Singapore: who and what benefits? Journal of Educational Administration, 36(1), 29-43. https://doi.org/10.1108/09578239810200123

Bullard, G. L. (2017). The impact of peer mentoring on student nurses. Dissertation Abstracts International: Section B: The Sciences and Engineering, 793. https://doi.org/10.1108/JARHE10-2015-0078

Celoria, D., \& Roberson, I. (2015). New Principal Coaching as a Safety Net. Educational Leadership and Administration: Teaching and Program Development, 26(March), 86-99.

Chapman, C., Lowden, K., Chestnutt, H., Hall, S., McKinney, S., \& Hulme, M. (2014). Research on the impact of the School Improvement Partnership Programme: Interim Report. Interim Report. Project Report. Education Scotland, Livingston., (August), 29.

Daly, C., \& Milton, E. (2017). External mentoring for new teachers: mentor learning for a change agenda. International Journal of Mentoring and Coaching in Education, 6(3), 178-195. https://doi.org/10.1108/IJMCE-03-2017-0021

Darling-hammond, L., LaPointe, M., Meyerson, D., Orr, M. T., \& Cohen, C. (2007). Preparing School Leaders for a Changing World: Lessons from Exemplary Leadership Development Programs. In School Leadership Study.

Dutton, C. (2003). Mentoring: the contextualisation of learning - mentor, protégé and organisational gain in higher education. Education + Training, 45(1), 22-29. https://doi.org/10.1108/00400910310459644

Eddy, P. L. (2013). Developing leaders: The role of competencies in rural community colleges. Community College Review 41(1): 20-43

Hansford, B., \& Ehrich, L. C. (2006). The principalship: how significant is mentoring? Journal of Educational Administration, 44(1), 36-52. https://doi.org/10.1108/09578230610642647

Hill, J. (2016). Perceptions of the school administrators of lowa's prinicipal mentoring and induction program. Western Illinois University.

Holland, E. (2018). Mentoring communities of practice: what' $s$ in it for the mentor? 
INTERNATIONAL JOURNAL OF ACADEMIC RESEARCH IN BUSINESS AND SOCIAL SCIENCES

Vol. 9, No. 11, November, 2019, E-ISSN: 2222-6990 @ 2019 HRMARS

International Journal of Mentoring and Coaching in Education, 7(2), 110-126. https://doi.org/10.1108/IJMCE-04-2017-0034

Hollenbeck, G. P., McCall, W. M. J. \& Silzer, R. F. (2006). Leadership competency models. The Leadership Quarterly 17(4): 398-413.

Institut Aminudin Baki, K. (2016). Kajian Impak Program Lawatan Bimbingan dan School Improvement Partner+ (SIPartner+).

Kementerian Pelajaran Malaysia. (2012). Pelan Strategik Interim Kementerian Pelajaran Malaysia 2011 - 2020 (B. P. dan P. D. Pendidikan, Ed.). Putrajaya: Perpustakaan Negara Malaysia.

Kementerian Pendidikan Malaysia. (2017). Panduan Pengurusan Program Transformasi Daerah 3.0 (3rd ed.; B. P. S. Harian, Ed.).

King, J., M. L., Review, L., Version, D., Kuratko, D. F., Santora, J. C., Seaton, W., ... Garrido, M. (2017). Leadership : its importance in the management of school coexistence. Procedia Social and Behavioral Sciences, 10(2), 1-11. https://doi.org/10.1016/j.sbspro.2017.02.059

Kunalan, K. (2016). Pengaruh peranan School Improvement Partner (SIPARTNER) terhadap kepimpinan pengetua dan pencapaian sekolah menengah di negeri Sabah. Universiti Malaysia Sabah.

Lejonberg, E., Elstad, E., \& Christophersen, K. A. (2015). Mentor education: challenging mentors' beliefs about mentoring. International Journal of Mentoring and Coaching in Education, 4(2), 142-158. https://doi.org/10.1108/IJMCE-10-2014-0034

Liang, J., \& Augustine-Shaw, D. (2016). Mentoring and induction for new assistant principals: the Kansas Educational Leadership Institute. International Journal of Mentoring and Coaching in Education, 5(3), 221-238. https://doi.org/10.1108/IJMCE-05-2016-0044

McNair, D.E., Duree, C.A. \& Ebbers, L. 2011. If I knew then what I know now: Using the leadership competencies developed by the American Association of Community Colleges to prepare community college presidents. Community College Review 39(1): 3-25.

$\mathrm{Ng}$, P. T. (2012). Mentoring and coaching educators in the Singapore education system. International Journal of Mentoring and Coaching in Education, 1(1), 24-35. https://doi.org/10.1108/20466851211231602

Peiser, G., Ambrose, J., Burke, B., \& Davenport, J. (2018). The role of the mentor in professional knowledge development across four professions. International Journal of Men, 7(1), 2-18. https://doi.org/10.1108/IJMCE-07-2017-0052

Pernamasari, R. (2018). Implementation of Good Corporate Governance and Voluntary Disclosure Compliance: 100 Compass Index Companies Listed Indonesian Stock Exhange (IDX) 2015-2016, International Journal of Academic Research in Accounting, Finance and Management Sciences 8 (2): 235-249.

Ragins, B. R., \& Kram, K. E. (2007). The landscape of mentoring in the 21st century. In The Handbook of Mentoring at Work: Theory, Research, and Practice.

https://doi.org/10.4135/9781412976619

Ragins, B. R., \& Kram, K. E. (2008). The Handbook of Mentoring at Work: Theory, Research, and Practice (3rd Editio). https://doi.org/10.4135/9781412976619

Russo, E. (2013). E-mentoring for new principals : A case study of a mentoring program. George 
INTERNATIONAL JOURNAL OF ACADEMIC RESEARCH IN BUSINESS AND SOCIAL SCIENCES

Vol. 9, No. 11, November, 2019, E-ISSN: 2222-6990 @ 2019 HRMARS

Mason University.

Sani, M., Zabidi, A., Razak, A., \& Banu, H. (2013). Smart Principals and Smart Schools. Procedia Social and Behavioral Sciences, 103, 826-836.

https://doi.org/10.1016/j.sbspro.2013.10.404

Sciarappa, K., \& Y. Mason, C. (2014). National principal mentoring: does it achieve its purpose? International Journal of Mentoring and Coaching in Education, 3(1), 51-71. https://doi.org/10.1108/IJMCE-12-2012-0080

Shanks, R. (2017). Mentoring beginning teachers: professional learning for mentees and mentors. International Journal of Mentoring and Coaching in Education, 6(3), 158-163. https://doi.org/10.1108/IJMCE-06-2017-0045

Sharifah Sofiah, A. R., \& Mohd Izham, M. H. (2017). Pelaksanaan program SIPartnerst dan hubungannya dengan standard kualiti pendidikan Malaysia di Sekolah Menengah. Seminar Serantau 2017, 338-354.

Siti Anida, M. (2012). Buku Panduan Pengurusan SIPartner: Pelaksanaan Program School Improvement Partner (SIPartner)-Program Pembangunan Prestasi Sekolah (SIP) 2010-2012. Institut Aminudin Baki: Percetakan Walina.

Tahir, L., Said, M. N. H. M., Daud, K., Vazhathodi, S. H., \& Khan, A. (2016). The benefits of headship mentoring: An analysis of Malaysian novice headteachers' perceptions. Educational Management Administration \& Leadership, 44(3), 420-450.

https://doi.org/10.1177/1741143214549973

Tan, S. Y. (2015). Pelaksanaan Program SIPartners+ di Negeri Johor. Universiti Teknologi Malaysia.

Vangronigen, B. A., Meyers, C. V, \& Hitt, D. H. (2017). A rubcric for assessing schools' plans for rapid improvement. Retrieved from http://centeronschoolturnaround.org

Wang, L. H., Gurr, D., \& Drysdale, L. (2016). Successful school leadership: case studies of four Singapore primary schools. Journal of Educational Administration, 54(3), 270-287. https://doi.org/10.1108/JEA-03-2015-0022

Weinberg, F. J., Mulki, J. P., Lankau, M. J., Wang, L. H., Gurr, D., Drysdale, L., ... Dutton, C. (2017). Professional development for heads: The role of mentor- ing. International Journal of Mentoring and Coaching in Education, 4(3), 666-681.

https://doi.org/10.1108/00400910310459644

Zachary, L. J. (2000). The Mentor's Guide (1st Editio). California: Jossey-Bass. 